\author{
TADEUSZ BoCHEŃSKI \\ Uniwersytet Szczeciński, Polska \\ University of Szczecin, Poland
SEBASTIAN WojTKIEWICZ
Uniwersytet Szczeciński, Polska \\ University of Szczecin, Poland
}

\title{
Import taboru kolejowego do Polski
}

\section{Import of Rolling Stock to Poland}

Streszczenie: Autorzy postanowili zbadać, jaka była rola importu taboru kolejowego i jego elementów w zaspokojeniu potrzeb polskiego rynku kolejowego oraz skąd pochodził importowany tabor. Zakres czasowy badań objął lata 1945-2017, ale ze względu na różne uwarunkowania gospodarcze analizę przeprowadzono w trzech okresach: 1945-1989, 1990-2001 i 2002-2018. W badaniach pominięto tabor parowy oraz wagony, a skupiono się na elektrycznych i spalinowych jednostkach trakcyjnych. Uwzględniono także kwestie związane z importem technologii i podzespołów do produkcji tego rodzaju taboru na terenie Polski. Wskazano uwarunkowania sprowadzania taboru z zagranicy, miejsce produkcji importowanych pojazdów eksploatowanych w Polsce oraz kraje, w których były one użytkowane, jeśli sprowadzono je jako używane. W okresie PRL import taboru odbywał się głównie w ramach RWPG. Z importu pochodziła znaczna część taboru spalinowego, zaś tabor elektryczny produkowano głównie w kraju. Istotne znaczenie miał zakup licencji na produkcję podzespołów i lokomotyw elektrycznych w Europie Zachodniej. W latach dziewięćdziesiątych XX wieku znacząco spadło zapotrzebowanie na tabor, w tym także na jego import. Natomiast po otwarciu rynku kolejowego w 2002 roku zapotrzebowanie na tabor istotnie wzrosło, co przełożyło się także na zwiększony import - najpierw używanego, a potem nowego taboru. Współcześnie sprowadzano z zagranicy przede wszystkim lokomotywy oraz podzespoły do produkcji taboru w kraju - głównie z Niemiec.

\begin{abstract}
The authors examined the role of rolling stock import and its elements in meeting the needs of the Polish rail market and the sources of the imported rolling stock. The time range of the research covered the years 1945-2017, but due to different economic conditions, the analysis was carried out for three periods: 1945-1989, 1990-2001 and 2002-2018. In the research, the steam locomotives were omitted, and the analysis covered electric and diesel rolling stock. Issues related to the import of technologies and components for rolling stock production in the country were also taken into account. The conditions of importing the rolling stock from abroad, the place of production of imported vehicles operated in Poland and the countries in which they were used, if they were imported as used, were indicated. Import of rolling stock in the PPR took place mainly within the frame of CMEA. A significant part of the diesel rolling stock came from import, and the electric rolling stock was largely produced in the country. Important were the purchase of licenses for the production of electric locomotives and components for its production in Western Europe. In the 1990s, the demand for rolling stock decreased significantly and this also included import. However, after the opening of the railway market in 2002, the demand for rolling stock increased and so did the imports - first used vehicles and later new rolling stock. Currently, locomotives and components for rolling stock production in the country were imported from abroad.
\end{abstract}


Słowa kluczowe: import taboru kolejowego; import technologii do produkcji; produkcja taboru kolejowego; tabor kolejowy w Polsce

Keywords: production of rolling stock; rolling stock import; rolling stock in Poland; technology import for production

Otrzymano: 22 grudnia 2018

Received: 22 December 2018

Zaakceptowano: 23 maja 2019

Accepted: 23 May 2019

Sugerowana cytacja / Suggested citation:

Bocheński, T., Wojtkiewicz, S. (2019). Import taboru kolejowego do Polski. Prace Komisji Geografii Przemysłu Polskiego Towarzystwa Geograficznego, 33(3), 17-35. doi: 10.24917/20801653.333.2

\section{WSTĘP}

Tabor kolejowy eksploatowany przez polskich przewoźników pochodził zarówno z produkcji krajowej, jak i z importu. O produkcji i modernizacji taboru kolejowego w Polsce po 1990 roku pisali na łamach niniejszego czasopisma S. Wojtkiewicz i T. Bocheński (2018).

Celem badań przedstawionych w artykule było określenie znaczenia importu taboru kolejowego dla zaspokojenia potrzeb polskiego rynku kolejowego oraz identyfikacja zakładów, z których pochodził tabor sprowadzony do Polski z zagranicy.

Zakres czasowy badań objął lata 1945-2017, ale ze względu na różne uwarunkowania gospodarcze analizę przeprowadzono w trzech okresach: Polska Ludowa 19451989 oraz Rzeczpospolita Polska w latach 1990-2001 i 2002-2018. W badaniach pominięto tabor parowy, a skupiono się na elektrycznych i spalinowych jednostkach trakcyjnych. Zwrócono także uwagę na import technologii i podzespołów do tego rodzaju taboru produkowanego na terenie Polski. Bardziej szczegółowo przeanalizowano okres po otwarciu rynku kolejowego w 2002 roku.

Zebrano i zaprezentowano dane o wielkości importu taboru kolejowego według jego rodzaju (lokomotywy, zespoły trakcyjne) oraz tego, czy były to pojazdy nowe, czy używane. Omówiono także uwarunkowania sprowadzania taboru z zagranicy. Wskazano miejsce produkcji importowanych pojazdów eksploatowanych w Polsce oraz kraje, w których były one użytkowane, jeśli sprowadzono je jako używane. Część współcześnie produkowanego taboru była wytwarzana przez duże koncerny mające zakłady w wielu miejscach na terenie różnych państw. Za tabor importowany uznano również taki, którego elementy powstawały w Polsce, ale finalny montaż odbywał się za granicą.

Ważnym źródłem informacji o taborze kolejowym eksploatowanym w Polsce były artykuły publikowane w czasopiśmie „Technika Transportu Szynowego”, m.in. autorstwa M. Graffa (2007, 2012a, 2012b, 2013, 2014a, 2014b, 2017). Zawierają one informacje o pojazdach trafiających do poszczególnych użytkowników w Polsce, w tym o liczbie sprowadzanych pojazdów oraz ich dane techniczne. Pewne informacje zawierają także artykuły w prasie branżowej, m.in. „Rynek Kolejowy” i „InfoRail”. W artykule pominięto import wagonów - głównie ze względu na brak źródeł dotyczących wagonów towarowych oraz trudności w znalezieniu wiarygodnych i pełnych danych o wagonach pasażerskich. Pewne trudności napotkano również przy poszukiwaniu wiarygodnych źródeł co do liczby lokomotyw sprowadzanych po 2002 roku przez przewoźników towarowych. 
Część z nich była dzierżawiona, niekiedy na stosunkowo krótki okres, co dodatkowo utrudniało badania. Ponadto przewoźnicy Freightliner i CTL Logistic to międzynarodowe koncerny posiadające filie w wielu krajach i operujący w znacznej części Europy. Wiązało się to niekiedy z relokacją taboru pomiędzy filiami w poszczególnych krajach.

\section{IMPORT TABORU KOLEJOWEGO I TECHNOLOGII DO JEGO PRODUKCJI W POLSCE LUDOWEJ}

W pierwszych latach powojennych bardzo ważne znaczenie miała pomoc UNRRA (Organizacja Narodów Zjednoczonych do spraw Pomocy i Odbudowy), w ramach której dostarczono m.in. parowozy amerykańskie. Część taboru, w tym parowozy i wagony, pochodziła z demobilu armii amerykańskiej - zbędne pojazdy od 1948 roku przekazywane były zachodnim strefom okupacyjnym Niemiec, a następnie ich część trafiła do Europy Środkowo-Wschodniej (Skodlarski, 1987).

Tuż po zakończeniu wojny władze komunistyczne nawiązały kontakty handlowe z krajami skandynawskimi, a głównym partnerem handlowym stała się Szwecja (Skodlarski, 1987). W 1949 roku powstała Rada Wzajemnej Pomocy Gospodarczej (RWPG), zrzeszająca kraje tzw. demokracji ludowej, a głównymi partnerami handlowymi PRL stały się Związek Radziecki (25-40\% wartości importu i eksportu) oraz Niemiecka Republika Demokratyczna (Rocznik statystyczny handlu zagranicznego 2016, 2016). Zakupy taboru za granicą odbywały się od tego czasu w przeważającej większości w krajach RWPG: Związku Radzieckim (ZSRR), Czechosłowackiej Republice Socjalistycznej (CSRS), Rumuńskiej Republice Ludowej (RRL), Niemieckiej Republice Demokratycznej (NRD), Węgierskiej Republice Ludowej (WRL) i Socjalistycznej Federacyjnej Republice Jugosławii (SFRJ). Tabor dla PKP pochodził także z krajów Europy Zachodniej: ze Szwecji, z Wielkiej Brytanii i z Włoch. Importowany do PRL tabor trakcyjny pochodził od 15 producentów z ośmiu państw. Poniżej wymieniono producentów, lata dostaw i odbiorców zagranicznego taboru (Zintel, 2003, 2005; Korcz, 2006; Terczyński, 2007, 2010; Rusak, 2008b; Goździewicz, 2017; Lokomotywy spalinowe..., 2018):

a) lokomotywy elektryczne

- Lokomotivbau Elektrotechnische Werke w Hennigsdorf, NRD - 4 sztuki E04 dla PKP (1954-1955) oraz 53 wąskotorowe na tor 900 mm EL3 (1955-1964) i 62 normalnotorowe EL2 (1958-1987) dla kopalni węgla brunatnego,

- NEWZ Nowoczerkask, ZSRR, 1978-1982 - 50 sztuk 112E (ET42) dla PKP,

- Skoda Pilzno, CSRS, 1961 i 1975-1978 - 90 sztuk dla PKP, w tym 30 sztuk 44E (EU05) zbudowanych pierwotnie na licencji szwajcarskiej firmy Sècheron oraz 60 sztuk 77E (ET40),

- Vulcan Foundry English Electric w Newton-le-Willows, Wielka Brytania, 19621964 - 20 sztuk AE IE (EU06) dla PKP;

b) lokomotywy spalinowe:

- Brianska Fabryka Lokomotyw, 1976-1988 - 86 sztuk TEM2 (SM42) dla PKP,

- ČKD Praha, CSRR, 1966-1990 - 309 sztuk kilku serii dla kolei przemysłowych, w tym 60 sztuk dla huty Katowice i ponad 100 dla kolei piaskowych w GOP,

- Electroputere Craiova, RRL, 1965-1978 - 422 sztuki 060DA na licencji szwajcarskiej (ST43) dla PKP,

- FAUR 23 August Werke Bucuresti, RRL - 150 sztuk LDE1300 (SP32) w latach 19851991 dla PKP oraz około 300 wąskotorowych na różne szerokości toru, w tym 214 sztuk L45H (Lxd2) i 80 sztuk L30H (Lyd2) dla PKP i kolei przemysłowych, 
- Ganz-MÁVAG, WRL, 1958-1961 - 10 sztuk SM40 i 264 sztuk SM41 dla PKP,

- Ludinowskij Tiepłowozostroitielnyj Zawod, ZSRR 1963 - 2 sztuki TGM3 (SM15) dla PKP wraz z licencją do ich produkcji w kraju,

- ŁTZ Woroszyłowgrad, ZSRR (obecnie: Ługańsk, Ukraina), 1966-1988 - 1184 sztuk M62 (ST44), w tym 68 szerokotorowych dla PKP LHS, 2 dla PMPPW, a pozostałe dla PKP;

c) elektryczne zespoły trakcyjne (EZT):

- Allmanna Svenska Elektriska Aktiebolaget, Szwecja, 1950-1956 - 44 sztuki EW54 dla PKP,

- VEB Waggonbau Görlitz, NRD, 1955-1958 - 38 sztuk dla PKP, w tym 36 sztuk EN56 i 2 sztuki ED70,

d) spalinowe zespoły trakcyjne i wagony motorowe (SZT):

- Ganz-MÁVAG Budapest, WRL, 1954-1975 - 304 sztuki dla PKP, w tym 54 sztuki SN52 i SN60 oraz 250 sztuk SN61,

- OM Mediolan, Włochy, 1951 - 3 sztuki SD80 dla PKP,

- FAUR 23 August Werke Bucuresti, RRL, 1984-1988 - 32 sztuki wąskotorowych A20D-P (MBxd2) i 100 wagonów doczepnych A208P (Bxhpi) dla PKP.

Po II wojnie światowej potrzebny był nowy tabor elektryczny do obsługi kolei w aglomeracji warszawskiej, którego nie były w stanie dostarczyć powoli uruchamiane zakłady krajowe. Pierwsze zamówienie na EZT, a potem także elektrowozy, złożono w Szwecji w 1946 roku, a dostawy nastąpiły w latach 1950-1956 (Kroma, 1995; Terczyński, 2010). W 1948 roku zawarto umowę na dostawę silników i aparatury elektrycznej produkcji angielskiej. Elementy te wykorzystano do odbudowy pojazdów EW52 oraz budowy nowych zespołów trakcyjnych - EW53 i lokomotyw EP02 w kraju (Trakcja elektryczna, 2018). W latach 1962-1964 zakupiono w Wielkiej Brytanii elektrowozy AE IE - oznaczone przez PKP jako EU06 - oraz licencję do ich dalszej produkcji w kraju. Na ich podstawie powstała, produkowana już w całości w Polsce, seria pojazdów oznaczonych jako EU07 (55 lat lokomotyw EU06, 2017). W późniejszej krajowej produkcji taboru korzystano z podzespołów na licencjach zagranicznych, np. w spalinowozach SP45/SU45 produkowanych w latach 1970-1976 wykorzystano prądnice francuskiej firmy Alsthom i silniki włoskiego Fiata (Irteński, 2013).

Na przełomie lat pięćdziesiątych i sześćdziesiątych dostarczono do PRL kilkadziesiąt lokomotyw elektrycznych normalno- i wąskotorowych produkcji wschodnioniemieckiej, które trafiły głównie na koleje przemysłowe kopalni węgla brunatnego. Zelektryfikowaną kolej wąskotorową KWB Turów wykorzystywano do połowy lat osiemdziesiątych XX wieku, a KWB Konin do końca lat pięćdziesiątych XX wieku - tę drugą zastąpiono potem normalnotorową. Natomiast KWB Adamów od początku, czyli od 1959 roku, miała kolej normalnotorową (Ciechański, 2013). Lokomotywy te nadal są eksploatowane w Polsce - 27 w KWB Konin i 13 w KWB Adamów (Rudziński, 2009; Chiżyński, 2011). Do prowadzenia pociągów ekspresowych zakupiono lokomotywy czechosłowackie EU05.

Inny wschodnioniemiecki zakład - VEB Waggonbau Görlitz wyprodukował dla PKP nowe EZT oraz zmodernizował 10 przedwojennych E91, które zostały oznaczone jako EW52. Wśród nowych EZT znalazły się 2 zespoły serii ED70, dostarczone w 1958 roku i służące do obsługi szybkich pociągów dalekobieżnych o wysokim standardzie (Terczyński, 2007, 2010). W ramach reparacji wojennych PKP otrzymały m.in. 189 wagonów berlińskiej kolei miejskiej S-Bahn. Po remoncie i przebudowie odbiorników prądu 
Rycina 1. Rozmieszczenie zakładów produkujących tabor trakcyjny importowany do PRL

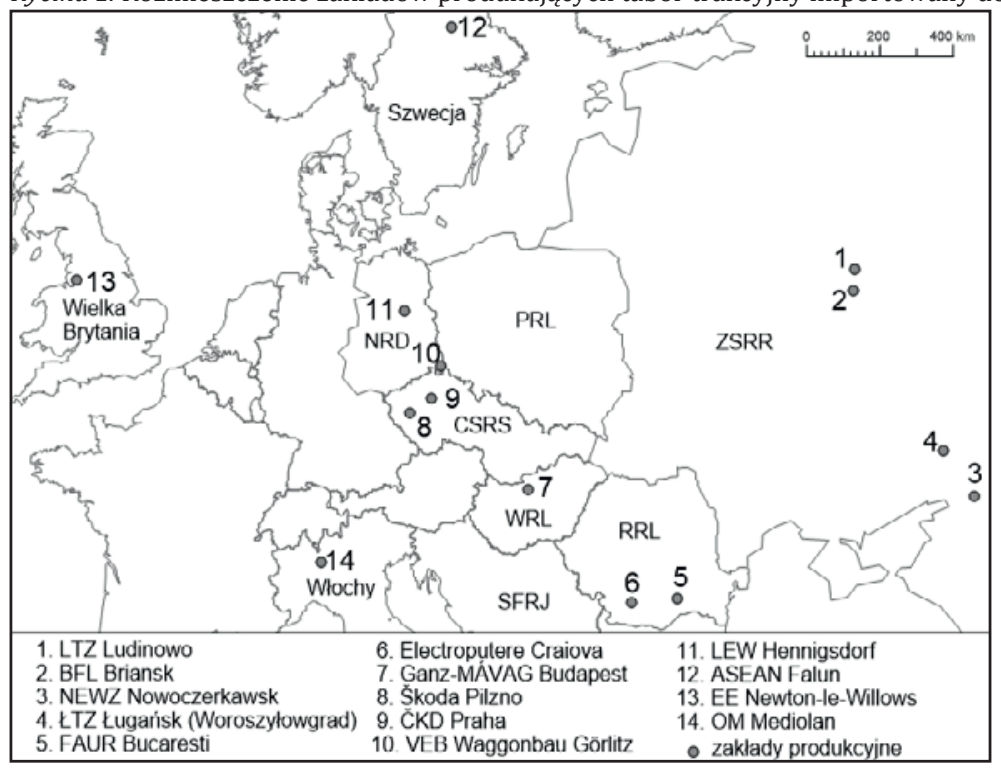

Źródło: opracowanie własne

Tabela 1. Import spalinowych i elektrycznych pojazdów trakcyjnych do PRL

\begin{tabular}{|c|c|c|c|c|c|c|c|c|c|c|}
\hline \multirow{3}{*}{ Państwo } & \multirow{3}{*}{ Razem } & \multicolumn{6}{|c|}{ Lokomotywy } & \multirow{2}{*}{\multicolumn{2}{|c|}{ SZT }} & \multirow{3}{*}{$\frac{\mathrm{EZT}}{\mathrm{n}}$} \\
\hline & & \multirow{2}{*}{ Razem } & \multicolumn{2}{|c|}{ elektryczne } & \multicolumn{3}{|c|}{ spalinowe } & & & \\
\hline & & & $\mathrm{n}$ & $\mathrm{w}$ & $\mathrm{n}$ & $\mathrm{S}$ & $\mathrm{w}$ & $\mathrm{n}$ & w & \\
\hline $\begin{array}{l}\text { Produkcja } \\
\text { krajowa* }\end{array}$ & 8330 & 6874 & 2548 & - & & & 4334 & 6 & - & 1450 \\
\hline Import ogółem & 3613 & 3100 & 230 & 53 & 2398 & 72 & 347 & 319 & 32 & 162 \\
\hline $\begin{array}{l}\text { Europa } \\
\text { Zachodnia }\end{array}$ & 75 & 28 & 28 & - & - & -- & - & 3 & - & 44 \\
\hline Szwecja & 52 & 8 & 8 & - & - & - & - & - & - & 44 \\
\hline Wielka Brytania & 20 & 20 & 20 & - & - & - & - & - & - & - \\
\hline Włochy & 3 & 0 & - & - & - & - & - & 3 & - & - \\
\hline $\begin{array}{l}\text { Razem kraje } \\
\text { RWPG }\end{array}$ & 3538 & 3072 & 202 & 53 & 2398 & 72 & 347 & 316 & 32 & 118 \\
\hline ZSRR & 1365 & 1365 & 50 & - & $\begin{array}{r}1 \\
245 \\
\end{array}$ & 70 & - & - & - & - \\
\hline RRL & 898 & 866 & - & - & $572^{\mathrm{a}}$ & - & 294 & - & 32 & - \\
\hline CSRS & 399 & 399 & 90 & - & 307 & 2 & - & - & - & - \\
\hline WRL & 578 & 274 & - & - & 274 & - & - & 304 & - & - \\
\hline NRD & 298 & 168 & 62 & 53 & - & - & 53 & 12 & - & $118^{\mathrm{b}}$ \\
\hline
\end{tabular}

SZT - spalinowe zespoły trakcyjne i wagony motorowe, EZT - elektryczne zespoły trakcyjne,

$\mathrm{n}$ - normalnotorowy (1435 mm), s - szerokotorowy (1520 mm), w - wąskotorowy (600, 750, 900, 1000 mm).

* Dane szacunkowe z uwzględnieniem taboru, którego produkcję zakończono w 1992 roku.

a Zamówienie zakończono w 1991 roku, ${ }^{b} \mathrm{w}$ tym 80 używanych składów z berlińskiej S-Bahn.

Źródło: opracowanie własne na podstawie Terczyński (1999); Zintel (2003); Zintel (2005); Korcz (2006); Rusak (2008a, 2008b); Terczyński (2010); Szymajda (2015); Wróblewski (2018); Lokomotywy spalinowe... (2018) 
uzyskano łącznie 80 składów oznaczonych na PKP jako serie: EW90, EW91 i EW92. Wszystkie trafiły do powstającej kolei miejskiej w Trójmieście (Wróblewski, 2018).

W drugiej połowie lat siedemdziesiątych XX wieku PKP zakupiło ciężkie dwuczłonowe elektrowozy towarowe wyprodukowane w CSRS oraz w ZSRR - łącznie do PKP trafiło ponad 100 takich lokomotyw (Rusak, 2008b; Goździewicz, 2017). Pomimo stworzenia udanej konstrukcji ciężkiego elektrowozu w zakładach w Poznaniu RWPG nakazała wstrzymanie produkcji, gdyż miała ona pozostać domeną Związku Radzieckiego (Goździewicz, 2017). Zakupy te wynikały więc nie z braku technologii, ale ze względów politycznych.

Z importu pochodziły niemal wszystkie eksploatowane w PRL-u wagony motorowe i SZT. Pierwsze z nich sprowadzono z Włoch, a następnie z WRL. Pomimo planów nie udało się uruchomić produkcji tego typu taboru w kraju. Wynikało to m.in. z wyznaczenia CSRS jako głównego dostawcę wagonów silnikowych w RWPG. Podobne problemy spowodowały ograniczenie krajowej produkcji ciężkich lokomotyw spalinowych. Planowano więc zakup wagonów silnikowych w CSRS, jednak do transakcji nie doszło. Dodatkowo w latach 1954-1957 zakupiono w NRD 12 wagonów silnikowych służących do rewizji elektrycznej sieci trakcyjnej. Jednak w tym przypadku późniejsze wagony inspekcyjne były już produkowane w kraju (Terczyński, 1999). Natomiast wagony motorowe na kolejach wąskotorowych pochodziły przede wszystkim z RRL. Węgierskie wagony motorowe ze względu na wyeksploatowanie na początku lat dziewięćdziesiątych XX wieku zostały całkowicie wycofane z ruchu (Zajfer, 2013).

Oprócz taboru trakcyjnego sprowadzano także wagony pasażerskie różnych typów, przede wszystkim z NRD produkowane w zakładach VEB Waggonbau w Görlitz i w Bautzen oraz w SFRJ - zakłady GOŠA Smederevska Palanka (Baza wagonów kolejowych, 2018).

Z krajów socjalistycznych sprowadzono łącznie ponad 3 tys. lokomotyw - 99\% importu, w tym ponad 1,3 tys. - 44\%, z ZSRR (tabela 1, rycina 1). Tabor ten dostarczano zarówno do PKP, jak i do zakładów przemysłowych. Współcześnie wciąż użytkowanych jest wiele lokomotyw czeskich i radzieckich. Natomiast z lokomotyw rumuńskich w eksploatacji pozostały jedynie wąskotorowe. Wśród EZT pochodzących z zagranicy ponad 70\% pochodziło z NRD, a pozostałe ze Szwecji. Obecnie nie są już one eksploatowane.

Zdecydowana większość taboru elektrycznego - zarówno lokomotyw, jak i zespołów trakcyjnych - pochodziła z produkcji krajowej. Natomiast niewystarczająca była produkcja taboru spalinowego, której rozwój dodatkowo był hamowany ze strony RWPG (Graff, 2017). Z importu pochodziło ogółem ponad 35\% lokomotyw spalinowych, w tym głównie spalinowozy do prowadzenia ciężkich pociągów towarowych, produkowane w ZSRR. Ponadto sprowadzono około 8\% lokomotyw elektrycznych, około 10\% EZT i 98\% wagonów silnikowych. Wśród importowanych EZT około połowy stanowiły niemieckie pojazdy używane, otrzymane w ramach reparacji wojennych, natomiast pozostały tabor kupowany był jako nowy.

\section{IMPORT TABORU KOLEJOWEGO DO POLSKI W LATACH 1990-2001}

Po transformacji ustrojowej ograniczona została zarówno produkcja krajowa - przeznaczona głównie na rynek wewnętrzny, jak i import taboru. Było to spowodowane zapaścią kolei w Polsce - drastycznie zmniejszyły się przewozy, a co za tym idzie zapotrzebowanie na tabor, a PKP borykało się z licznymi problemami. 
W 1990 roku zakończyła się dostawa zamówionych jeszcze w okresie PRL-u lokomotyw czechosłowackich, a w 1991 roku rumuńskich (Rusak, 2008b). Jednak z powodu wysokiej awaryjności rumuńskie lokomotywy SP32 w 2017 roku zostały wycofane z eksploatacji (Za nieco ponad..., 2017).

PKP koncentrowało się na pozyskaniu nowego taboru do obsługi pociągów ekspresowych, kursujących głównie w relacjach międzynarodowych. Planowano zakup wagonów pasażerskich umożliwiających jazdę z prędkością 160 km/godz., dwusystemowych elektrowozów, a także pociągów dużych prędkości. Ze względu na brak produkcji tego typu taboru, a także odpowiedniej technologii w kraju, planowano pozyskać go za granicą. Z planów tych zrealizowano jedynie zakup wagonów wyprodukowanych przez ABB Henschel AG Werk Siegen oraz VEB Waggonbau Görlitz.

W związku z zamiarem uruchomienia szybkich połączeń między wybranymi miastami zaistniała potrzeba zakupu nowych lokomotyw elektrycznych dostosowanych do jazdy z prędkością $160 \mathrm{~km} /$ godz. Wybrano 112E produkowane pierwotnie w zakładzie ABB Technomasio w Vado Ligure we Włoszech. Ich produkcję w 1997 roku rozpoczęto w zakładzie Adtranz-Pafawag we Wrocławiu - oba zakłady, w Polsce i we Włoszech, należą obecnie do koncernu Bombardier. Pierwsze trzy pojazdy wyprodukowano we Włoszech, a kolejnych pięć w zakładzie Pafawag w Polsce (Graff, 2012a).

PKP zamierzało także pozyskać EZT dużych prędkości. W 1994 roku na testy przyjechał do Polski prototyp pendolino - skład ETR460 produkcji Fiat Ferroviaria. W 1997 roku PKP ogłosiły przetarg na 16 składów z wychylnym pudłem tego typu, do transakcji jednak nie doszło. Najwyższa Izba Kontroli przeprowadziła kontrolę, w której wykazała rażące uchybienia w postępowaniu przetargowym oraz niegospodarność PKP. W Polsce nie było wówczas żadnego fragmentu linii kolejowej przystosowanej do jazdy z prędkością ponad $160 \mathrm{~km} /$ godz. W 1999 roku przetarg na wniosek NIK został unieważniony (Informacja o wynikach kontroli..., 2000).

Utworzona w 1993 roku spółka Lubuskie Koleje Regionalne zakupiła od kolei duńskich DSB 10 używanych zestawów pociągowych typu push-pull serii VT 11.5 oraz znaczną ilość części zamiennych. Każdy taki skład złożony był z lokomotywy spalinowej, wagonu środkowego i wagonu z kabiną sterowniczą. Co do zasady składy te przypominały zatem SZT, ponieważ były dwukierunkowe. Pociągi te przeznaczone były do obsługi połączeń dalekobieżnych i były bardzo komfortowe jak na polskie warunki, m.in. posiadały klimatyzację. W Polsce kursowały jednak po lokalnych liniach kolejowych z niewielkimi potokami podróżnych. Po upadku LKR część składów została zezłomowana, a niektóre znalazły inne zastosowanie (Fularz, 2004; Bocheński, 2012).

Od 1990 roku głównym partnerem handlowym Polski stały się Niemcy - kumulując ponad 20\% wartości naszego importu i eksportu (Rocznik statystyczny handlu zagranicznego 2016, 2016). Z tego też państwa pochodziła od tej pory większość importowanego taboru kolejowego, a także podzespołów do jego produkcji w kraju.

\section{IMPORT TABORU KOLEJOWEGO DO POLSKI PO 2001 ROKU}

Na początku XXI wieku sytuacja kolei w Polsce uległa diametralnej zmianie. W 2002 roku rynek kolejowy został otwarty i zaczęli pojawiać się na polskich torach nowi przewoźnicy, początkowo towarowi, a potem także pasażerscy. Kilka lat później samorządy województw przejęły od państwa organizację kolejowych przewozów regionalnych. 
Sytuacja ta wpłynęła na zwiększenie zapotrzebowania na tabor kolejowy zarówno dla ruchu towarowego, jak i pasażerskiego.

Początkowo sprowadzano używane SZT z Europy Zachodniej. Tego typu pojazdów najbardziej brakowało, a krajowi producenci nie mieli jeszcze doświadczenia w ich produkcji.

Do Polski trafiło m.in. 37 pojazdów silnikowych i pięć wagonów doczepnych produkcji Düwag Waggonfabrik Uerdingen AG różnych serii (Rusak 2008a, 2008b; Graff, 2012b; Graff, 2013; Graff, 2014a, 2014b; Fiszer, 2017a; Szymajda, 2018), sprowadzonych przez:

- województwo zachodniopomorskie - 14 składów VT624 (SA110) i 5 wagonów doczepnych pochodzących z 1964-1968, dzierżawionych w latach 2006-2012 od DB Regio,

- Mazowiecką Spółkę Taborową - 11 składów serii VT627.0, VT627.1 i VT628 z lat 1974-1975 i 1981 roku pozyskanych z Niemiec od DB Regio,

- Sigma Tabor - 10 składów serii DH1 (SN82) i 2 sztuki DH2 (SN82) pochodzących z lat 1981-1983, zmodernizowanych w 1996 roku, zakupionych w 2009 roku w Holandii od Veolia,

- Górnośląskie Przedsiębiorstwo Wodociągowe - 2 składy serii VT614 (SN84) z 1973 roku pozyskane w 2011 roku z Niemiec od DB Regio dla Kolei Śląskich,

- Arriva PCC (obecnie Arriva RP) - pojedynczy skład serii Y kupiony w 2010 roku w Danii od DSB.

Ponadto Arriva sprowadziła siedem składów MR+MRD wyprodukowanych w latach 1978-1985 przez Scandia Randers w Danii i zmodernizowanych w latach 19951997 (Piech, 2008; Graff, 2013) oraz na przełomie lat 2013 i 2014 dzierżawiła dwa zespoły VT646 produkcji Stadler Rail od DB Regio Nord-Ost.

Pojazdy zakupione przez Sigma Tabor po remoncie i polonizacji w poznańskim ZNTK były dzierżawione: Przewozom Regionalnym Sp. z o.o. - zakład pomorski w latach 2010-2013, Kolejom Mazowieckim - jeden w latach 2010-2011 i Kolejom Śląskim w latach 2012-2014 (Graff, 2012b). SZT, które miały służyć Kolejom Śląskim, trafiły do Górnośląskiego Przedsiębiorstwa Wodociągów (GPW), należącego do samorządu województwa śląskiego - były to cztery pojazdy dostarczone za pośrednictwem Sigma Tabor oraz dwa składy sprowadzone z Niemiec, które jednak nie uzyskały dopuszczenia do eksploatacji na sieci kolejowej PKP (Madrjas, 2018a).

W międzyczasie polscy producenci PESA i NEWAG wyspecjalizowali się w produkcji SZT i po 2011 roku zasadniczo zaprzestano importu tego typu pojazdów. Regionalni przewoźnicy i PR eksploatowali stare składy spalinowe do momentu zakupu fabrycznie nowych produkcji krajowej. Jedynie prywatny przewoźnik SKPL w 2017 roku sprowadził z Czech używane wagony motorowe serii 810, tzw. motoraki, wyprodukowane przez Vagonka Studénka w latach 1976-1982 i eksploatowane przez ČD. Kursowały one m.in. na trasie Lipusz-Bytów oraz w Pleszewie (Fiszer, 2017a, 2017b). SKPL w 2018 roku odkupiło także pojazdy należące do GPW i wykorzystywało je do obsługi przewozów na Podkarpaciu (Madrjas, 2018b; Szymajda, 2018).

Ogółem w latach 2005-2011 sprowadzono do Polski z Europy Zachodniej łącznie 47 wagonów i zespołów spalinowych oraz pięć wagonów doczepnych. Wagony doczepne i 15 motorowych po okresie dzierżawy zostały zwrócone. Poza tym pojazd Y należący do Arriva stanowił rezerwę taborową, zaś jeden pojazd SA110 stał się pojazdem muzealnym. W 2017 roku trafiły do Polski cztery wagony motorowe z Czech. 
Inaczej kształtował się import taboru dla przewoźników towarowych. Po otwarciu rynku kolejowego w Polsce pojawiło się wielu nowych przewoźników. Wzrosło zatem zapotrzebowanie na tabor. Ze względu na problemy w pozyskaniu taboru w kraju prywatni przewoźnicy w znacznej części sprowadzali pojazdy z zagranicy. Dotyczyło to zwłaszcza używanych lokomotyw. Państwowy przewoźnik PKP Cargo celowo sprzedawała na złom wycofany, ale sprawny tabor, aby uniemożliwić jego wykorzystanie przez innych przewoźników, którzy byli zainteresowani jego zakupem. Często główne elementy, czyli rama i wózki, musiały być fizycznie skasowane pod nadzorem sprzedającego. W latach 2001-2008 PKP Cargo skasowały w ten sposób około 10\% swoich lokomotyw. Podobnie zresztą postępowały Przewozy Regionalne Sp. z o.o., które w tym samym okresie skasowały około 33\% swoich wagonów pasażerskich. Prywatni przewoźnicy musieli więc szukać taboru za granicą. Starali się oni pozyskać pojazdy tych samych typów, które były już w Polsce eksploatowane, aby uniknąć problemów z ich dopuszczeniem do ruchu po sieci PKP (Zajfert, 2013; Taylor, Ciechański, 2017). Popularne były zwłaszcza elektrowozy produkcji czeskiej Škoda, różnych serii, oraz radzieckie spalinowozy. W 2004 roku Rail Polska ściągnęła np. 36 lokomotyw M62 z Estonii (Rail Polska, 2017). Podobne lokomotywy produkcji radzieckiej sprowadzano także z Niemiec - były to wyprodukowane dla kolei wschodnioniemieckich i oznaczone przez Deutsche Reichsbahn jako serie V200 i V300 (Rusak, 2008b). Prywatni przewoźnicy sprowadzili do Polski kilkadziesiąt lokomotyw elektrycznych produkcji Škoda Pilzno, różnych serii pochodzących z lat sześćdziesiatych i siedemdziesiątych XX wieku (Rusak, 2008a). Najnowocześniejsze ze sprowadzonych do Polski używanych lokomotyw były dwusystemowe elektrowozy BR1822. Wyprodukowano je w latach 1992-1996 przez Simmering-Graz-Pauker dla austriackich kolei ÖBB. W 2005 roku dwa takie pojazdy zakupiła spółka PTKiGK Rybnik, przejęta potem przez DB Schenker Rail Polska. Lokomotywy te jeździły jednak wyłącznie po Polsce, przez co nie wykorzystywano ich dwusystemowości (Rusak, 2008a). Część przewoźników prywatnych wywodzących się z kombinatów przemysłowych posiadało lokomotywy spalinowe - głównie pojazdy produkcji ČKD Praha, które zostały zakupione jeszcze w PRL-u na potrzeby obsługi bocznic zakładów przemysłowych (Rusak, 2008a). Kilka sztuk używanych lokomotyw serii 201Eg (ET22) sprowadzono z Maroka. Były to jednak pojazdy polskiej produkcji wcześniej eksportowane do tego kraju.

Ogółem w latach 2004-2017 do Polski trafiło ponad 50 używanych spalinowych zespołów trakcyjnych i wagonów motorowych, wraz z kilkoma wagonami doczepnymi, oraz kilkadziesiąt używanych lokomotyw spalinowych i elektrycznych (rycina 2).

Importowany używany tabor wymagał polonizacji i uzyskania świadectwa dopuszczenia do ruchu na polskich torach od UTK. Polonizacja to dostosowanie do polskich wymogów bezpieczeństwa i sterowania ruchem kolejowym. Polegała ona m.in. na wyposażeniu pojazdu w: reflektory halogenowe, układ czuwaka aktywnego (CA), układ samoczynnego hamowania pociągu (SHP), układ łączności radiowej wraz z układem zdalnego zatrzymania „radiostop” - radiotelefon Pyrylandi. Niekiedy montowano także pantografy i prędkościomierz polskiej konstrukcji (Rusak, 2008a, 2008b). Sprowadzenie pojazdów serii, które już wcześniej uzyskały dopuszczenie do ruchu i poruszały się po polskich torach, było łatwiejsze. Dlatego m.in. tak popularny był import lokomotyw radzieckich i czeskich, które od lat były użytkowane także na polskich torach.

W 2006 roku rozpoczęto import nowego taboru. Województwo mazowieckie zakupiło 11 lokomotyw Traxx P160DC (EU47) - nazwanych „Hetmanami”, oraz 
Rycina 2. Pochodzenie taboru kolejowego pochodzącego z importu i użytkowanego w Polsce

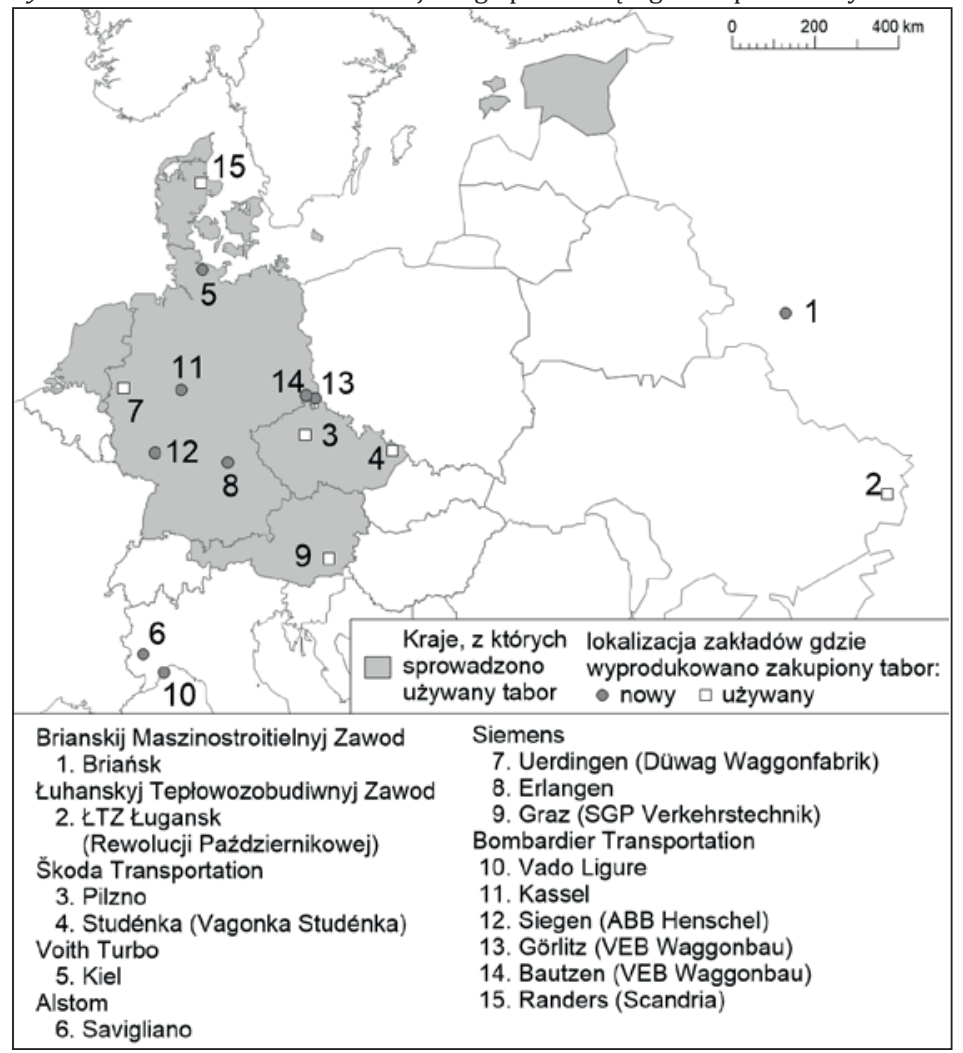

Źródło: opracowanie własne

37 wagonów piętrowych, w tym 11 sterowniczych, wyprodukowanych przez Bombardier Transportation w zakładzie w niemieckim Görlitz. Posłużyły one do zestawienia pociągów typu push-pull, czyli dwukierunkowych (Koleje Mazowieckie, 2017; Push-pulle..., 2017). W latach 2008-2009 PKP Intercity zakupiło 10 wielosystemowych lokomotyw elektrycznych EuroSprinter ES64U4 produkcji Siemensa - nazwanych „Husarzami” (Warszawa: Husarz..., 2008). Służą one do obsługi pociągów międzynarodowych pomiędzy Polską a Niemcami - dzięki temu nie ma potrzeby zmiany lokomotyw na granicy ze względu na inne napięcie w sieci trakcyjnej w tych krajach. W 2011 roku przewoźnik ten podpisał umowę na zakup EZT dużej prędkość - 20 składów ETR610 „Pendolino” produkcji Alstom powstało w zakładzie we włoskim Savigliano (Szybciej..., 2011) (rycina 2). Od grudnia 2014 roku składy te kursują jako pociągi kategorii EIP w barwach PKP Intercity. Zakup ten budził w Polsce duże kontrowersje. Trzeba jednak pamiętać, że polscy producenci nie byli jeszcze w tamtym czasie zdolni do wyprodukowania taboru dużych prędkości, a taki był niezbędny, aby w pełni wykorzystać możliwości zmodernizowanej z unijnym dofinansowaniem linii E65 Gdańsk-Warszawa-Katowice. Warto także wspomnieć, że już w połowie lat dziewięćdziesiątych XX wieku PKP przymierzało się do zakupu pociągów typu pendolino.

Nowe lokomotywy za granicą kupowali, a częściej brali w dzierżawę lub leasing, najwięksi przewoźnicy towarowi. Były to (Rusak, 2008a, 2008b; Koclega, 2009; Gravita 
10BB..., 2012; Graff, 2017; LOTOS Kolej rozpoczyna..., 2017; Komplet Vectronów..., 2017; Madrjas, 2018c):

a) elektrowozy Traxx produkowane przez Bombardier Transportation w Kassel, Niemcy

- F140MS (EU43) w leasingu od Railpool - 6 sztuk w 2008 roku dla PKP Cargo i 14 sztuk w 2010 roku dla Lotos,

- F140MS (E186) - 16 sztuk w latach 2006-2011 dla różnych przewoźników towarowych,

- F140DC (E485) - 2 sztuki w 2011 roku i 2 sztuki wydzierżawione od Akiem w 2016 roku dla Pol-Miedź-Trans;

b) elektrowozy EuroSprinter i Vectron produkowane przez Siemens Mobility w Erlangen, Niemcy

- ES64U4 (EU44) - 5 sztuk dzierżawionych od Dispolok przez CTL Logistic od 2007 i 2008 roku,

- ES64F4 (EU45) - po 9 sztuk dla PKP Cargo i ITL Polska w latach 2009-2011 i 2 sztuki dla LOTOS Kolej w 2010 roku,

- MS - 23 sztuki dla DB Cargo w latach 2010-2015,

- DC (EU46) - 15 sztuk dla PKP Cargo w latach 2015-2017;

c) spalinowozy różnych producentów

- Brianskij Maszinostroitielnyj Zawod, Briansk, Rosja - 7 sztuk szerokotorowej TEM18, w tym 1 dla CZH w Katowicach w 2006 roku i 6 dla PKP LHS w 2008 roku,

- Electro-Motive Diesel, USA - 39 sztuk Class 66, w tym 24 dla Freightliner PL w latach 2006-2018 oraz 15 sztuk w 2011 roku dla DB Schenker Rail Polska,

- Voith Turbo Kilonia, Niemcy - 3 sztuki Gravita 10BB w latach 2011-2012 i 2 sztuki Voith Maxima 40CC w 2009 roku dla Lotos Kolej,

- Bombardier Transportation w Kassel, Niemcy - 10 sztuk F140DE (BR285) w 2011 roku dla Lotos Kolej.

Jedyną lokomotywą pochodzącą spoza Europy była amerykańska Class 66 przeznaczona do ciągnięcia ciężkich składów towarowych (Freightliner Pl, 2018; Madrjas, 2018c). Część lokomotyw Class 66 należących do Freightliner było wcześniej użytkowanych przez brytyjskiego operatora tej międzynarodowej korporacji, ale wszystkie wyprodukowano po 2001 roku. Przewoźnik ten, jako jedyny w kraju, posiadał w całości nowy tabor trakcyjny produkcji zagranicznej (Zajfert, 2013).

Bardzo popularne w Europie, w tym wśród największych przewoźników w Polsce, stały się modułowe lokomotywy Bombardier Transportation serii Traxx. Poszczególne części tych lokomotyw były produkowane w kilku zakładach: pudła we Wrocławiu, wózki i część mechaniczna w Siegen, część elektryczna i system sterowania w Mannheim i Hennigsdorf, a montaż finalny wykonywany był w Kassel w Niemczech lub w Vado Ligure we Włoszech. Lokomotywy użytkowane w Polsce były serwisowane w zakładzie koncernu we Wrocławiu (Graff, 2007).

W związku z otwartym rynkiem kolejowym niektórzy polscy przewoźnicy posiadali licencje na przewozy w innych państwach UE, np. PKP Cargo w 2013 roku w sześciu państwach poza Polską (Bocheński, 2016). Spowodowało to pojawienie się zapotrzebowania na wielosystemowe elektrowozy, w których produkcji wyspecjalizowały się koncerny Bombardier i Siemens. Dopiero w 2013 roku wyprodukowano w Polsce pierwszą tego typu lokomotywę (Pierwsza polska..., 2013). 
Ogółem w latach 2004-2017 do Polski trafiło około 185 nowych lokomotyw zagranicznej produkcji, w tym część była dzierżawiona lub leasingowana. Większość z nich użytkowali przewoźnicy towarowi. Ponadto za granicą zakupiono 20 EZT dużych prędkości (tabela 2).

Tabela. 2. Import taboru trakcyjnego na potrzeby przewoźników pasażerskich w Polsce w latach 2005-2017

\begin{tabular}{|l|r|r|r|r|r|r|c|}
\hline \multicolumn{1}{|c|}{ Lata } & 2005 & 2006 & 2007 & 2008 & 2009 & 2010 & 2011 \\
\hline Używane SZT & 11 & 14 & - & 7 & 10 & 1 & 2 \\
\hline Nowe EZT & - & - & - & - & - & - & - \\
\hline Nowe lokomotywy & - & 11 & - & - & 2 & 8 & - \\
\hline Lata & 2012 & 2013 & 2014 & 2015 & 2016 & 2017 & suma \\
\hline Używane SZT & - & - & - & - & - & 4 & 49 \\
\hline Nowe EZT & - & 4 & 16 & - & - & - & 20 \\
\hline Nowe lokomotywy & - & - & - & - & - & - & 21 \\
\hline
\end{tabular}

Nie uwzględniono składów dzierżawionych na okres krótszy niż rok.

Źródło: opracowanie własne na podstawie informacji publikowanych przez PKP IC, Koleje Mazowieckie, Urząd Marszałkowski woj. zachodniopomorskiego, Graff (2014b)

Wyraźnie zmieniły się kierunki importu taboru w obecnej Polsce w porównaniu z PRL. Od początku XXI wieku większość importowanego taboru pochodziła z Niemiec - dotyczyło to zarówno nowych lokomotyw i wagonów, jak i sprowadzanych wcześniej spalinowych zespołów trakcyjnych. W Niemczech znajdowały się główne europejskie zakłady Bombardiera, zlokalizowane w takich ośrodkach jak: Siegen, Bautzen, Görlitz i Kassel. Kontynuowały one tradycje przemysłu kolejowego innych zakładów w tych miastach. Istotne znaczenie miały Czechy, skąd pochodziła znaczna liczba lokomotyw importowana jako nowe w okresie PRL i po 2002 roku jako pojazdy używane. Zakłady w dawnych krajach socjalistycznych przestały mieć znaczenie. Jedynie z Briańska w Rosji kupiono współcześnie do Polski kilka lokomotyw szerokotorowych. Z tej fabryki pochodziła również bardzo popularna wśród prywatnych kolejowych przewoźników towarowych na polskim rynku lokomotywa M62. Była ona jednak często poddawana już w polskich zakładach głębokiej modernizacji i z oryginału niewiele pozostawało. Istotnym dostawcą taboru stały się Włochy - znajdował się tam zakład ALSTOM, który wyprodukował pendolino dla PKP IC, oraz jeden z zakładów Bombardiera, gdzie dokonywano finalnego montażu lokomotyw TRAXX (rycina 2).

W latach 2002-2017 z produkcji krajowej, która trafiła do polskich przewoźników, pochodziło ponad 500 zespołów trakcyjnych i ponad 50 lokomotyw (Graff, 2017; Wojtkiewicz, Bocheński, 2018). Import z zagranicy w tym okresie stanowił 5,3\% zakupionych EZT, 18,9\% zakupionych SZT i wagonów motorowych. Wszystkie importowane SZT były pojazdami używanymi i większość z nich zastąpiono w późniejszym okresie nowymi pojazdami krajowej produkcji. W 2017 roku sprowadzono z zagranicy jeszcze kilka używanych wagonów motorowych, a jednocześnie produkowano SZT w kraju. W zakresie lokomotyw produkcja krajowa była niewielka i większość pojazdów pochodziła z importu - ponad 90\% spalinowozów i ponad 70\% elektrowozów. Część nowych lokomotyw przewoźnicy pozyskiwali w ramach dzierżawy lub leasingu. Importowany tabor sprowadzany był głównie z Niemiec (tabela 3). 
Tabela 3. Pochodzenie spalinowych i elektrycznych pojazdów trakcyjnych, które trafiły do polskich przewoźników kolejowych w latach 2002-2017

\begin{tabular}{|c|c|c|c|c|c|c|c|}
\hline \multirow{3}{*}{ Państwo } & \multicolumn{3}{|c|}{ Używany } & \multicolumn{4}{|c|}{ Nowy, w tym dzierżawa } \\
\hline & \multicolumn{2}{|c|}{ lokomotywy } & \multirow{2}{*}{$\begin{array}{c}\text { zespoły } \\
\text { spalinowe }\end{array}$} & \multicolumn{2}{|c|}{ lokomotywy } & \multicolumn{2}{|c|}{ zespoły trakcyjne } \\
\hline & elektryczne & spalinowe & & elektryczne & spalinowe & spalinowe & elektryczne \\
\hline Ogółem & $\mathrm{x}$ & $\mathrm{x}$ & $\mathrm{x}$ & 121 & 71 & 219 & 380 \\
\hline Polska* & $\mathrm{x}$ & $\mathrm{x}$ & $\mathrm{x}$ & 45 & 10 & 219 & 360 \\
\hline $\begin{array}{l}\text { Razem } \\
\text { import }\end{array}$ & $(>30)$ & $(>50)$ & 51 & 76 & 61 & - & 20 \\
\hline Austria & 2 & - & - & - & - & - & - \\
\hline Estonia & - & 36 & - & - & - & - & - \\
\hline Czechy & $(30)^{\mathrm{a}}$ & b.d. & 4 & - & - & - & - \\
\hline Niemcy & - & 17 & $29^{b}$ & $76^{\mathrm{b}}$ & 15 & - & - \\
\hline Dania & - & - & 8 & - & - & - & - \\
\hline Holandia & - & - & 10 & - & - & - & - \\
\hline Włochy & - & - & - & - & - & - & 20 \\
\hline Rosja & - & - & - & - & 7 & - & - \\
\hline USA & - & - & - & - & $39^{c}$ & - & - \\
\hline
\end{tabular}

(...) dane szacunkowe, * w latach 2002-2016.

a Potwierdzono sprowadzenie 16 pojazdów i kilkunastu innych.

b W tym część pojazdów dzierżawiono.

c W tym część używana wcześniej przez brytyjską część koncernu Freightliner.

Źródło: opracowanie własne

Oprócz całych pojazdów istotne znaczenie miał import podzespołów wykorzystywanych w produkcji krajowej. Ze względu na brak produkcji niektórych elementów, np. silników wysokoobrotowych, duża część podzespołów do produkowanych i modernizowanych w XXI wieku w Polsce pojazdów szynowych pochodziła z zagranicy, m.in. z Niemiec, Czech, Austrii i Francji. Od producentów niemieckich pochodziły m.in. silniki - produkcji MAN i MTU, układy hamulcowe - Knorr-Bremse, i przekładnie osiowe - Voith (specyfikacje techniczne pojazdów). Silniki spalinowe produkcji MTU były bardzo często stosowane w lokomotywach oraz SZT produkowanych przez polskich producentów. Z silników tej firmy korzystali m.in. dwaj najwięksi polscy producenci taboru kolejowego - PESA i NEWAG (Wach, 2014). MTU, będąca częścią Rolls-Royce Power Systems AG, jest jednym z wiodących na świecie producentów silników spalinowych do różnych pojazdów mechanicznych. Natomiast w większości SZT wyprodukowanych przez ZNTK Poznań użyto silników MAN (Graff, 2014b). W lokomotywach ST40 powstałych w zakładach PESA Bydgoszcz w ramach modernizacji radzieckich M62 zastosowano amerykańskie silniki General Electric (Irteński, 2013).

Za import technologii do produkcji taboru kolejowego można uznać lokalizację w Polsce zakładów należących do zagranicznych koncernów. W 1997 roku zakłady Pafawag we Wrocławiu zostały wykupione przez grupę Adtranz, która w 2001 roku została przejęta przez kanadyjski koncern Bombardier Transportation. Natomiast w 2007 roku zakład w Polsce otworzył szwajcarski koncern Stadler (Wojtkiewicz, Bocheński, 2018). 


\section{WPŁYW OTWARCIA RYNKU KOLEJOWEGO W EUROPIE NA PRODUKCJE I ZAPOTRZEBOWANIE NA TABOR}

Jak wskazuje Y. Sato (2005), równolegle z restrukturyzacją i integracją kolei europejskich następowała restrukturyzacja sektora produkcji taboru kolejowego. Produkcja ta skupiła się w dużej mierze w trzech międzynarodowych koncernach: Alstom Transport, Siemens i Bombardier. Natomiast Y. Crozet (2017) zauważa, że po liberalizacji rynku kolejowego nowi przewoźnicy kolejowi są źródłem innowacji, m.in. w taborze kolejowym. W związku z otwartym rynkiem kolejowym w UE i umożliwieniem prowadzenia przewozów międzynarodowych na całej trasie przez jednego przewoźnika pojawiło się zapotrzebowanie na elektrowozy wielosystemowe, dostosowane do ruchu po liniach z różnym napięciem sieci trakcyjnej. Ich wykorzystanie pozwalało na prowadzenie pociągów międzynarodowych bez konieczności zmiany lokomotywy w przypadku zmiany zasilania. W Europie w poszczególnych krajach przyjęto bowiem różne systemy zasilania trakcji elektrycznej na kolei. Produkcja tego typu lokomotyw rozpoczęła się w 2004 roku, głównymi producentami stały się koncerny Bombardier i Siemens, a pojazdy te były dostępne także w leasingu (Joint locomotive..., 2013).

Posiadanie odpowiedniego taboru często stanowiło barierę wejścia na rynek nowych przewoźników, zwłaszcza prywatnych. W tej sytuacji zasiedziałe, państwowe przedsiębiorstwa posiadały przewagę konkurencyjną, zwłaszcza że niekiedy zakup przez nie taboru był współfinansowany przez państwo lub dzięki państwowym gwarancjom mogły one uzyskać lepsze warunki kredytowe - wskazują na to m.in. badania (Beria, Quinet, de Rus, Schulz, 2010).

Na rynku kolejowym pojawiły się wyspecjalizowane przedsiębiorstwa zajmujące się dzierżawą lub leasingiem taboru kolejowego (Bruckmann, Bomhauer-Beins, Weidmann, 2015), np. Railpool, Akiem, Dispolok. Oferowały one lokomotywy wraz z serwisem, w tym wielosystemowe elektrowozy Bombardier TRAXX i Siemens Vectron. Powodowało to brak konieczności posiadania własnego taboru przez przewoźników. Z leasingu taboru korzystali głównie przewoźnicy towarowi.

Wszystkie powyższe aspekty widoczne były na polskim rynku kolejowym.

\section{PODSUMOWANIE}

Import taboru miał różne znaczenie w poszczególnych okresach, a także w odniesieniu do rodzaju importowanych pojazdów (tabela 4). Był ściśle związany z produkcją w kraju, dotyczył bowiem pojazdów, których krajowy przemysł w danym czasie nie mógł z różnych przyczyn dostarczyć.

Tabela 4. Szacunkowy udział importu w dostawach nowych kolejowych pojazdów trakcyjnych na polski rynek

\begin{tabular}{|l|c|c|c|c|}
\hline \multirow{2}{*}{ Okres } & \multicolumn{2}{|c|}{ Lokomotywy } & \multicolumn{2}{c|}{ Zespoły trakcyjne } \\
\cline { 2 - 5 } & elektryczne & spalinowe & spalinowe* & elektryczne \\
\hline $1945-1989 * *$ & $8,3 \%$ & $35,6 \%$ & $98,2 \%$ & $10,0 \%$ \\
\hline $1990-2001$ & - & - & $58,8 \%$ & - \\
\hline $2002-2017$ & $70,2 \%$ & $91,0 \%$ & $18,9 \%$ & $5,3 \%$ \\
\hline
\end{tabular}

* W tym pociągi spalinowe typu push-pull.

** Uwzględniono lokomotywy, których dostawy zakończyły się w 1992 roku.

Źródło: opracowanie własne 
Duże zapotrzebowanie na tabor w PRL-u wynikało m.in. ze znacznych wielkości przewozów pasażerskich i towarowych w tym okresie. Łącznie na polski rynek do 1992 roku, nie licząc parowozów, trafiło prawie 12 tys. pojazdów trakcyjnych (tabela 4). Czynnikiem determinującym kierunki i wielkość importu, a także rodzaj produkowanego taboru w kraju była współpraca w ramach RWPG. Dlatego najwięcej importowanych lokomotyw normalno- i szerokotorowych pochodziło z ZSRR, a w zakresie taboru wąskotorowego dominował tabor z RRL. Z importu pochodziły wszystkie wagony motorowe oraz znaczna część lokomotyw spalinowych. Niewielka część taboru elektrycznego pochodziła ze Szwecji i Wielkiej Brytanii. Zakup lokomotyw w Wielkiej Brytanii powiązany był z uzyskaniem licencji na ich produkcję, a nabyte pojazdy stanowiły punkt wyjścia do budowy własnych konstrukcji w kraju. W tym ostatnim przypadku należy dodać, że Wielka Brytania jako kraj kolebki kolei dostarczała tabor do wielu krajów na świecie i dopiero pod koniec XX wieku znaczenie tego kraju w eksporcie taboru spadło (Sato, 2005). Elektrowozy importowano z tego państwa już w okresie międzywojennym (Irteński, 2013).

W latach dziewięćdziesiątych XX wieku znacząco spadło zapotrzebowanie na tabor. Wynikało to ze zmniejszenia przewozów kolejowych, zarówno pasażerskich, jak i towarowych, oraz trudnej sytuacji finansowej PKP. Załamaniu uległa produkcja krajowa, a import taboru trakcyjnego został ograniczony do wcześniej zakontraktowanych pojazdów i całkowicie ustał w latach 1993-2003.

W latach dziewięćdziesiątych XX wieku z importu pochodziły nowe wagony dla pociągów ekspresowych PKP oraz używane pociągi spalinowe dla LKR. Po otwarciu rynku kolejowego w 2002 roku wzrosła liczba przewoźników i zapotrzebowanie na tabor, co przełożyło się także na zwiększony import. Rozpoczęto na większą skalę sprowadzanie używanego taboru z zagranicy oraz zakupy nowego.

W pierwszej dekadzie XXI wieku w Polsce rozpoczęło się stopniowe odejście od składów wagonowych w kierunku zespołów trakcyjnych, co wiązało się z wymianą taboru. Do obsługi pasażerskiego ruchu regionalnego sprowadzano SZT i wagony motorowe wycofane z kolei duńskich, holenderskich, niemieckich i czeskich. Tabor ten był w większości wykorzystywany do czasu rozwinięcia się produkcji tego typu pojazdów w Polsce. Z czasem tabor ten był wycofywany i zastępowany nowymi pojazdami. Aktualnie pojazdy tego typu produkcji zagranicznej użytkowane są jedynie przez dwóch prywatnych przewoźników: Arriva i SKPL. Restrukturyzacja rodzimych zakładów taboru i uruchomienie w Polsce zakładów Stadlera powoduje, że większość nowych SZT i EZT jest i zapewne nadal będzie produkowana w kraju. Ponadto ze względu na koszty znaczne ilości taboru, zarówno polskiej, jak i zagranicznej produkcji, poddawano modernizacji w krajowych zakładach, co zmniejszało popyt na nowe pojazdy (por. Wojtkiewicz, Bocheński, 2018).

Do obsługi pociągów ekspresowych PKP Intercity zakupiło pochodzące z importu nowe elektryczne lokomotywy wielosystemowe oraz EZT dużych prędkości typu pendolino. Były to pojazdy, których w momencie zapotrzebowania nie mogli dostarczyć krajowi producenci.

Przewoźnicy towarowi spoza grupy PKP sprowadzali używane lokomotywy, gdyż nie mogli ich pozyskać w kraju - wynikało to z polityki PKP Cargo, która wolała złomować swoje pojazdy niż sprzedawać je do dalszej eksploatacji. Popularne były zwłaszcza lokomotywy produkcji radzieckiej i czeskiej tych serii, które były już wcześniej w Polsce użytkowane. Ułatwiało to procedury związane z dopuszczeniem pojazdu do 
eksploatacji na sieci PKP PLK. Po sprowadzeniu do Polski lokomotywy te często przechodziły naprawy główne lub modernizację. Do Polski trafiły również nowe lokomotywy amerykańskie.

Najwięksi przewoźnicy towarowi kupowali lub dzierżawili nowe lokomotywy, zwłaszcza wielosystemowe elektrowozy produkowane w Europie Zachodniej - głównie w Niemczech. Lokomotywy wielosystemowe do niedawna nie były w Polsce produkowane.

Po transformacji ustrojowej większość importowanego taboru, a także podzespołów do jego produkcji w kraju, pochodziła z Niemiec. W 2015 roku według danych GUS 25,7\% wartości importu w zakresie taboru i infrastruktury transportu szynowego przypadało na Niemcy (Rocznik statystyczny handlu zagranicznego 2016, 2016).

Importowano nie tylko całe pojazdy, ale także podzespoły, wykorzystywane w krajowej produkcji. Było to spowodowane brakiem produkcji odpowiednich podzespołów w kraju, których pomimo prób rodzimy przemysł nie był w stanie dostarczyć.

W Polsce swoje zakłady posiadały także zagraniczne koncerny produkujące tabor kolejowy: kanadyjski Bombardier Transportation i szwajcarski Stadler.

W ostatnich latach znacząco rozwinął się przemysł taboru kolejowego w Polsce, produkowano coraz nowocześniejszy tabor przeznaczony nie tylko na rynek krajowy, ale i na eksport (Wojtkiewicz, Bocheński, 2018). Wpływa to na ograniczenie importu całych pojazdów. Ważnym czynnikiem jest także dostępność pojazdów, zwłaszcza lokomotyw w ramach leasingu.

Można wskazać trzy czynniki związane z liberalizacją kolei, które miały wpływ na zapotrzebowanie na tabor i jego import do Polski po 2002 roku:

- możliwość prowadzenia przewozów międzynarodowych przez jednego przewoźnika na terenie wielu państw europejskich - konieczność dysponowania taborem dopuszczonym do ruchu w tych krajach, a pojazdy polskiej produkcji tego warunku w większości jeszcze nie spełniały,

- przedsiębiorstwa zasiedziałe, np. PKP Cargo, pomimo znacznej nadpodaży taboru nie były skłonne do jego sprzedaży konkurencyjnym przewoźnikom prywatnym,

- powstanie przedsiębiorstw zajmujących się dzierżawą/leasingiem taboru kolejowego, oferujących lokomotywy najczęściej produkcji światowych koncernów dopuszczonych do ruchu w wielu krajach.

\section{Literatura \\ References}

55 lat lokomotyw EU06 (2017, 9 lutego). InfoRail. Pozyskano z http://m.inforail.pl/55-lat-lokomotyw-eu06_more_91778.html

Baza wagonów kolejowych (2018, 15 listopada). Pozyskano z http://bazawagonow.pl/

Beria, P., Quinet, E., de Rus, G., Schulz, C. (2010). A comparison of rail liberalisation levels across four European countries. 12 WCTR, Lisbona.

Bocheński, T. (2012). Koleje regionalne w Polsce. W: S. Sitek (red.). Stare i nowe problemy badawcze w geografii społeczno-ekonomicznej, Sosnowiec: Polskie Towarzystwo Geograficzne, Oddział Katowicki i Uniwersytet Śląski Wydział Nauk o Ziemi, 37-50.

Bocheński, T. (2016). Przemiany towarowego transportu kolejowego $w$ Polsce na przełomie XX i XXI wieku. Szczecin: Wydawnictwo Naukowe Uniwersytetu Szczecińskiego.

Bruckmann, D., Bomhauer-Beins, A., Weidmann, U. (2015). A Qualitative Model to Evaluate the Financial Effects of Innovations in the Rail Sector. Transportation Research Procedia, 10, 564-573. doi: 10.1016/j.trpro.2015.09.010 
Chiżyński, J. (2011). Atlas przewoźników kolejowych Polski. Rybnik: Eurosprinter.

Ciechański, A. (2013). Rozwój i regres sieci kolei przemysłowych w Polsce w latach 1881-2010. Prace Geograficzne, 243.

Crozet, Y. (2017). Rail freidht development in Europe: how to deal with a doubly-imperfect competition? Transportation Research Procedia, 25, 425-442. doi: 10.1016/j.trpro.2017.05.420

Fiszer, K. (2017a, 26 stycznia). Czeskie 810 w SKPL. Do połączeń całorocznych. Rynek Kolejowy. Pozyskano z https://www.rynek-kolejowy.pl/wiadomosci/czeskie-810-w-skpl-do połaczen-calorocznych-80018.html

Fiszer, K. (2017b, 10 kwietnia). SKPL: Dodatkowe kursy na Pleszewskiej KL. Rynek Kolejowy. Pozyskano z https://www.rynek-kolejowy.pl/wiadomosci/skpl-dodatkowe-kursy-na-pleszewskiej-kl-81171.html

Freightliner Pl (2018, 22 grudnia). Pozyskano z https://pl.freightliner.eu/pl/o-nas/nasz-tabor/ Fularz, A. (2004). LKR - Krótka historia pierwszej kolei samorządowej. Ekonomika Kolei, 1, 6-10.

Goździewicz, J. (2017, 23 grudnia). Kolej lat siedemdziesiątych w Polsce. Wspomnienia. Rynek Kolejowy. Pozyskano z https://www.rynek-kolejowy.pl/wiadomosci/kolej-lat-siedemdziesiatych-w-polsce-wspomnienia-84978.html

Graff, M. (2007). Lokomotywy Bombardiera TRAXX F140 MS dla PKP Cargo. Technika Transportu Szynowego, 12, 18.

Graff, M. (2012a). Lokomotywy elektryczne serii E405/E412 kolei włoskich. Technika Transportu Szynowego, 1-2, 45-48.

Graff, M. (2012b). Spalinowe wagony silnikowe i zespoły trakcyjne serii DH1 i DH2. Technika Transportu Szynowego, 12, 43-46.

Graff, M. (2013). Spalinowe zespoły trakcyjne serii MR+MRD i Y. Technika Transportu Szynowego, $5,30-33$.

Graff, M. (2014a). Spalinowe zespoły trakcyjne GTW Stadlera na sieci PKP PLK. Technika Transportu Szynowego, 1-2, 45-47.

Graff, M. (2014b). Pojazdy z napędem spalinowym dla ruchu regionalnego w Polsce. Technika Transportu Szynowego, 4, 25-34.

Graff, M. (2017). Przemysł taboru szynowego w Polsce. Technika Transportu Szynowego, 9, 17-34.

Gravita 10BB z certyfikatem UTK (2012, 31 maja). Kurier Kolejowy. Pozyskano z https://kurierkolejowy.eu./aktualności/8248/gravita-10bb-z-certyfikatem-utk.html

Informacja o wynikach kontroli prawidłowości przeprowadzenia przez Przedsiębiorstwo Państwowe Polskie Koleje Państwowe przetargów na wybór dostawy składów szybkich pociągów z wychylnym nadwoziem (2000, 19 stycznia). Warszawa: Departament Transportu, Gospodarki Morskiej i Łączności NIK.

Irteński, T. (2013). Lokomotywy. Polskie konstrukcje. Warszawa: Wydawnictwo SBM.

Joint locomotive pool and maintenance strategy (2013, kwietnia). COSMOS, Good Practice, 10. Pozyskano z http://www.intermodal-cosmos.eu/content/e4/e251/e259/e268/COSMOS_ WP1_Good-Practice-Manual_10_Joint-locomotive-pool_LM-HC_20130430_eng.pdf

Koclega, G. (2009, 6 lipca). Lokomotywa Voith Maxima 40 CC w Lotos Kolej. Rynek Kolejowy. Pozyskano z: https://www.rynek-kolejowy.pl/wiadomosci/lokomotywa-voith-maxima-40-cc-w-lotos-kolej-61088.html

Koleje Mazowieckie (2017, 15 grudnia). Pozyskano z http://www.mazowieckie.com.pl/

Komplet Vectronów w PKP CARGO, pora na PKP Intercity? (2017, 5 maja). InfoRail. Pozyskano z http://inforail.pl/komplet-vectronow-w-pkp-cargo-pora-na-pkp-intercity-_more_94131. html

Korcz, P. (2006). Atlas wąskotorówek. Poznań: Poznański Klub Modelarzy Kolejowych.

Kroma, R. (1995). Lokomotywa elektryczna EP03. Świat Kolei, 1, 31.

Lokomotywy spalinowe serii SM40 i SM41 (2018, 15 grudnia). Skansen Taboru Kolejowego w Chabówce. Pozyskano z https://www.parowozy.pl/ekspozycja/spalinowe/sm40-sm41/

LOTOS Kolej rozpoczyna eksploatację pierwszej lokomotywy TRAXX F140 DE (2011, 1 lipca). Pozyskano z http://www.lotos.pl/322/p,174,n,3406/grupa_kapitalowa/centrum_prasowe/ aktualnosci/lotos_kolej_rozpoczyna_eksploatacje_pierwszej_lokomotywy_traxx_f140_de

Madrjas, J. (2018a, 11 stycznia). SKPL przemaluje składy kupione z GPW. Ale jeszcze nie wiadomo, gdzie pojadą. Rynek Kolejowy. Pozyskano z https://www.rynek-kolejowy.pl/wiadomosci/skpl-przemaluje-sklady-kupione-z-gpw-ale-jeszcze-nie-wiadomo-gdzie-pojada-85225.html 
Madrjas, J. (2018b, 19 stycznia). Jakie (jeszcze) pociągi muszą sprzedać wodociągi? Rynek Kolejowy. Pozyskano z https://www.rynek-kolejowy.pl/wiadomosci/jakie-jeszcze-pociagi-musza-sprzedac-wodociagi-85374.html

Madrjas, J. (2018c, 9 kwietnia). FPL: Do Polski jadą kolejne lokomotywy Class 66. Rynek Kolejowy. Pozyskano z https://www.rynek-kolejowy.pl/wiadomosci/fpl-do-polski-jada-kolejne-lokomotywy-class-66-86113.html

Piech, R. (2008, 18 lutego). Zespoły MR MRD Arriva PCC z dopuszczeniem do ruchu. InfoRail. Pozyskano z http://inforail.pl/zespoly-mr-mrd-arrivapcc-z-dopuszczeniem-do-ruchu_ more_65950.html

Pierwsza polska wielosystemowa lokomotywa zakończyła testy $(2013,14$ sierpnia). Nowy Przemyst. Pozyskano z https://logistyka.wnp.pl/pierwsza-polska-wielosystemowa-lokomotywa-zakonczyla-testy,204433_1_0_0.html

Push-pulle z Bombardiera dla Kolei Mazowieckich (2017, 15 grudnia). Railway Busines Forum. Pozyskano z http://www.rbf.net.pl/wiecej,Push-pulle-z-Bombardiera-dla-Kolei-Mazowieckich

Rail Polska Sp. z o.o. (2017, 15 grudnia). Pozyskano z http://www.railpolska.pl/ztk.html

Rocznik statystyczny handlu zagranicznego 2016 (2016). Warszawa: Główny Urząd Statystyczny. Rudziński, A. (2009). Koleje Górnicze KWB Konin. Technika Transportu Szynowego, 4-5, 78-83.

Rusak, R. (2008a). Pojazdy trakcyjne przewoźników prywatnych - lokomotywy elektryczne. Technika Transportu Szynowego, 3, 13-21.

Rusak, R. (2008b). Pojazdy trakcyjne przewoźników prywatnych - lokomotywy spalinowe. Technika Transportu Szynowego, 4, 31-45.

Sato, Y. (2005). Global market of rolling stock manufacturing: present situation and future potential. Japan Railway \& Transport Review, 41, 4-13.

Skodlarski, J. (1987). Stosunki handlowe Polski z krajami kapitalistycznymi (1945-1949). Kwartalnik Historyczny, 94(3), 125-144.

Szybciej, bezpieczniej i wygodniej - nowe pociagi z Programu Infrastruktura i Środowisko dla Intercity (2011, 23 sierpnia). Pozyskano z https://www.funduszeeuropejskie.2007-2013. gov.pl/wiadomosci/strony/20110822_intercity_rozwoj_transportu_kolejowego_pois.aspx

Szymajda, M. (2015, 24 grudnia). SD80. Czy dla unikalnego pojazdu jest jeszcze ratunek?, Rynek Kolejowy. Pozyskano z https://www.rynek-kolejowy.pl/wiadomosci/sd80-czy-dla-unikalnego-pojazdu-jest-jeszcze-ratunek-73824.html

Szymajda, M. (2018, 15 czerwca). SN84 „Mucha” w barwach SKPL już w Bieszczadach. Wkrótce zabierze pasażerów. Rynek Kolejowy. Pozyskano z https://www.rynek-kolejowy.plwiadomosci/sn84-mucha-w-barwach-skpl-juz-w-bieszczadach-wkrotce-zabierze-pasazerow-87460.html.

Taylor, Z., Ciechański, A. (2017). Deregulacja i przekształcenia przedsiębiorstw transportu lądowego w Polsce na tle polityki spójności UE. Prace Geograficzne, 257.

Terczyński, P. (1999). Spalinowe wagony silnikowe na Polskich Kolejach Państwowych. Technika Transportu Szynowego, 12, 19-29.

Terczyński, P. (2007). Atlas lokomotyw 2007. Poznań: Poznański Klub Modelarzy.

Terczyński, P. (2010). Elektryczne zespoły trakcyjne w Polsce - stan obecny i bliska perspektywa. Technika Transportu Szynowego, 5-6, 13-20.

Trakcja elektryczna (2018, 15 grudnia). Skansen Taboru Kolejowego w Chabówce. Pozyskano z https://www.parowozy.pl/ekspozycja/elektryczne/

Wach, K. (2014, 22 kwietnia). GAMY dla PKP IC z silnikami MTU serii 4000. InfoRail. Pozyskano z http://m.inforail.pl/gamy-dla-pkp-ic-z-silnikami-mtu-serii-4000_more_40549.html

Warszawa: Husarz PKP Intercity (2008, 11 grudnia). InfoRail. Pozyskano z http://www.inforail. $\mathrm{pl} /$ warszawa-husarz-pkp-intercity_more_63720.html

Wojtkiewicz, S., Bocheński, T. (2018). Rozwój przemysłu taboru kolejowego w Polsce na przełomie XX i XXI wieku. Prace Komisji Geografii Przemysłu Polskiego Towarzystwa Geograficznego, 32(3), 157-173. doi: 10.24917/20801653.323.10

Wróblewski, P. (2018, 15 grudnia). Historia i dzień dzisiejszy Szybkiej Kolei Miejskiej w Trójmieście. Pobrano z https://www.skm.pkp.pl/en/o-nas/nasza-historia/ 
Za nieco ponad trzy tygodnie SP32 zakończą służbę (2017, 5 grudnia). InfoRail. Pozyskano $\mathrm{z}$ http://inforail.pl/za-nieco-ponad-trzy-tygodnie-sp32-zakoncza-sluzbe_more_100936. html

Zajfert, M. (2013). Dostęp do taboru kolejowego barierą rozwoju rynku przewozów pasażerskich w Polsce. Internetowy Kwartalnik Antymonopolowy i Regulacyjny, 4(2), 89-109.

Zintel, K. (2003). Wąskotorowe lokomotywy elektryczne na tor $900 \mathrm{~mm}$ w kopalniach węgla brunatnego. Swiat Kolei, 6, 30-35.

Zintel, K. (2005). Lokomotywy elektryczne typu EL2. Świat kolei, 1, 14-21.

Tadeusz Bocheński, dr, adiunkt w Instytucie Geografii Społeczno-Ekonomicznej i Gospodarki Przestrzennej Uniwersytetu Szczecińskiego. Specjalizuje się w geografii transportu. Prowadzi badania z zakresu: funkcjonowania kolei i transportu intermodalnego, funkcjonowania portów morskich oraz powiązań między przemysłem a koleją i portami morskimi. Obszar badań obejmuje przede wszystkim Polskę, Europę Środkowo-Wschodnią i Region Morza Bałtyckiego. W polu jego zainteresowań znajduje się również delimitacja regionów funkcjonalnych w Polsce.

Tadeusz Bocheński, PhD, assistant professor in the Institute of Socio-Economic Geography and Spatial Management of the University of Szczecin. He specialises in transport geography. He conducts research in the field of: railway operation and intermodal transport, operation of seaports and links between industry and railways and sea ports. The research area mainly covers Poland, Central and Eastern Europe and the Baltic Sea Region. His field of interest also includes the delimitation of functional regions in Poland.

ORCID: 0000-0001-6172-7914

\section{Adres/address:}

Uniwersytet Szczeciński

Instytut Geografii Społeczno-Ekonomicznej i Gospodarki Przestrzennej

ul. Mickiewicza 18, 70-383 Szczecin, Polska

e-mail: tadeusz.bochenski@usz.edu.pl

Sebastian Wojtkiewicz, mgr inż., doktorant w Instytucie Geografii Społeczno-Ekonomicznej i Gospodarki Przestrzennej Uniwersytetu Szczecińskiego. Specjalizuje się w geografii transportu. Prowadzi badania m.in. z zakresu funkcjonowania kolei oraz komunikacji miejskiej. W polu jego zainteresowań znajdują się również przemiany przestrzenne w miastach.

Sebastian Wojtkiewicz, MSc, PhD student in the Institute of Socio-Economic Geography and Spatial Management of the University of Szczecin. He specialises in transport geography. He conducts research on the functioning of railways and public transport. His academic interests also include spatial changes in cities.

ORCID: 0000-0002-3044-0547

\section{Adres/address:}

Uniwersytet Szczeciński

Instytut Geografii Społeczno-Ekonomicznej i Gospodarki Przestrzennej

ul. Mickiewicza 18, 70-383 Szczecin, Polska

e-mail: sebastianwojtkiewicz@gmail.com 